Seminário de Pesquisa

Programa de Pós-Graduação

Design FAU USP

\title{
Aprendizado em design, mercado de trabalho e a necessidade de uma prática situada
}

\author{
Marcelo Silva Pinto, André Leme Fleury
}

\author{
design; prática do design; ensino
}

\begin{abstract}
A pesquisa visa compreender e identificar possíveis aprimoramentos a serem inseridos no ensino de design com recorte nos estados de Minas Gerais e São Paulo. A motivação principal reside na experiência acadêmica e profissional de 15 anos do pesquisador, que identificou a dificuldade de novos designers atuarem no mercado, embora tenham aumentado o número de vagas de graduação na área nos últimos anos. 0 trabalho parte do pressuposto de que, para que o aprendizado dos alunos de design voltado para mercado seja mais efetivo, é preciso caracterizar a prática como: estudantil, projetual, profissional e social do design (PINTO e CARVALHO, 2018). Como apresentado por Lave, J. \& Wenger (1991) a prática só pode ser aprendida na "situação", participando e legitimando-se em "uma comunidade prática" a partir da qual é vivenciado o tácito, que não pode ser explicitado. A coleta de informações teve início com a realização de pesquisa etnográfica digital (Murthy, 2008), considerando como base o Exame Nacional de Desempenho dos Estudantes (ENADE) e a realização de pesquisa exploratória com 200 estudantes e graduados sobre como avaliam o que é ofertado pelas instituições de ensino e o que é demandado pelo mercado. A análise dos dados coletados encontra-se na fase de confrontar os resultados do ENADE com a percepção obtida por meio da realização da pesquisa de satisfação de alunos em disciplinas de graduação da Universidade Federal de Minas Gerais. Os resultados preliminares validam a relevância sobre o estudo da lacuna de conhecimentos sobre a "prática situada" no design. O desafio é aplicar novos procedimentos para que consigamos traçar melhores formas de ensino/aprendizagem com foco na prática.
\end{abstract}

\section{André Leme Fleury}

Professor da Universidade de São Paulo, atuando nos cursos de Design (FAU), Engenharia de Produção (Poli) e Pró-Reitoria de Graduação (PRG-USP). Especialista em inovação, coordena diferentes iniciativas de formação de empreendedores na USP. e-mail: andre.fleury@usp.br Lattes: http://lattes.cnpq. br/1299755265131677

Orcid: https://orcid.org/00000003-4937-0339 


\title{
Design Learning, job market and necessity of a situated practice
}

Marcelo Silva Pinto, André Leme Fleury

\author{
design; design practice; teaching
}

The research intends to understand and identify possible improvements for the design education to be inserted in the states of Minas Gerais and São Paulo, Brazil. The main motivation stems from the researcher's 15-year academic and professional experience, which identified the difficulty for new designers to find work, although the number of graduate vacancies in the area has increased in recent years. The work starts from the assumption that, in order for design students to be more effective in their learning for the market, it is necessary to characterise the practice as: student practice, project practice, professional practice and social practice of design (PINTO e CARVALHO, 2018). As presented by Lave, J., \& Wenger (1991), practice can only be learned in the "situation", participating and legitimising itself in "a practical community" from which tacit is experienced, which cannot be explained. The collection of information started with the realisation of digital ethnographic research (Murthy, 2008), considering the National Examination of Student Performance (ENADE) and the conduct of exploratory research with 200 students and graduates on how to evaluate what is offered by educational institutions and what is demanded by the market. The analysis of the collected data is in the phase of comparing the results of ENADE with the perception obtained by conducting a student satisfaction survey in undergraduate courses at the Federal University of Minas Gerais. The preliminary results validate the relevance of studying the knowledge gap about "situated practice" in design. The challenge is to apply new procedures so that we can trace better forms of teaching / learning with a focus on practice.

\section{Referências | References}

LAVE, J. \& WENGER, E. 1991. Situated learning: Legitimate peripheral participation. New York: Cambridge University Press.

MURTY, D. 2008. Digital ethnography: An examination of the use of new technologies for social research. Sociology 42(5): 837-855.

PINTO, M. S; CARVALHO, L. S. C. 2018. Reflexões sobre o ensino e a prática do design no atual cenário brasileiro. In: Anais do Congreso Latinoamericano de Enseñanza del Diseño, 2018, Buenos Aires.

\section{André Leme Fleury}

Professor at the University of São Paulo, working in the courses of Design (FAU), Production Engineering (Poli) and Dean of Undergraduate Studies (PRGUSP). A specialist in innovation, he coordinates different entrepreneur training initiatives at USP.

e-mail: andre.fleury@usp.br

Lattes: http://lattes.cnpq. br/1299755265131677

Orcid: https://orcid.org/00000003-4937-0339 